\title{
Infection with Rhizoctonia solani Induces Defense Genes and Systemic Resistance in Potato Sprouts Grown Without Light
}

\author{
M. J. Lehtonen, P. Somervuo, and J. P. T. Valkonen
}

Plant Pathology Laboratory, Department of Applied Biology, FIN-00014 University of Helsinki, Finland. Accepted for publication 4 August 2008.

\begin{abstract}
Lehtonen, M. J., Somervuo, P., and Valkonen, J. P. T. 2008. Infection with Rhizoctonia solani induces defense genes and systemic resistance in potato sprouts grown without light. Phytopathology 98:1190-1198.

Rhizoctonia solani is an important soilborne and seedborne fungal pathogen of potato (Solanum tuberosum). The initial infection of sprouts prior to emergence causes lesions and may be lethal to the sprout or sprout tip, which results in initiation and compensatory growth of new sprouts. They emerge successfully and do not suffer significant damage. The mechanism behind this recovery phenomenon is not known. It was hypothesized that infection may induce pathogen defense in sprouts, which was investigated in the present study. Tubers were sprouted in cool

defense-related responses was monitored in the apical portion using microarray and quantitative polymerase chain reaction techniques at 48 and $120 \mathrm{~h}$ postinoculation (hpi) and by challenge-inoculation with $R$. solani in two experiments. Differential expression of 122 and 779 genes, including many well-characterized defense-related genes, was detected at 48 and $120 \mathrm{hpi}$, respectively. The apical portion of the sprout also expressed resistance which inhibited secondary infection of the sprouts. The observed systemic induction of resistance in sprouts upon infection with virulent $R$. solani provides novel information about pathogen defense in potato before the plant emerges and becomes photosynthetically active. These results advance our understanding of the little studied subject of pathogen defense in subterranean parts of plants.
\end{abstract} and moist conditions in darkness to mimic conditions beneath soil. The basal portion of the sprout was isolated from the apical portion with a soft plastic collar and inoculated with highly virulent $R$. solani. Induction of
Additional keywords: disease resistance, ecology, genomics, infection cycle, resource allocation, stem canker, transcriptome.
Rhizoctonia solani Kühn (teleomorph Thanatephorus cucumeris [Frank] Donk) infects at least 200 plant species and is one of the most common soilborne pathogens in crop plants $(29,58,59)$. Strains of $R$. solani belong to at least 14 different, genetically defined populations of anastomosis groups (AG) determined by anastomosis between hyphae of strains belonging to the same AG $(16,58)$. Potato (Solanum tuberosum L.) is mostly infected with isolates of AG-3 $(2,5,17)$, especially in the potato production areas under cool climates such as northern Europe (38). The various types of damage to the subterranean parts in infected plants eventually materialize as malformed tubers, increased proportion of small and overlarge tubers $(5,48$, $54,55,66)$, and considerable reduction of the marketable yield $(5,18)$.

Asexual, vegetatively growing, multinucleate hyphae of $R$. solani grow on the plant surface, attach within $12 \mathrm{~h}$, and form Tshaped branches in flattened hyphae. Penetration into the epidermal tissues and cortex takes place with thin and densely located infection pegs that form beneath clumps of hyphae (35). Further growth occurs inter- or intracellularly, and is associated with secretion of extracellular enzymes (29). Consequently, the infected tissues collapse and form brown lesions known as stem canker $(5,18)$. This disease develops mainly prior to emergence $(32,56,63)$. The pathogen continues to grow on roots and stolons and forms sclerotia on them, which is stimulated by senescence of the plant towards the end of the growing season. Sclerotia

Corresponding author: J. P. T. Valkonen; E-mail address: Jari.Valkonen@helsinki.fi

* The $e$-Xtra logo stands for "electronic extra" and indicates that the online version contains a table showing a list of differentially expressed potato genes.

doi:10.1094/PHYTO-98-11-1190

(C) 2008 The American Phytopathological Society remaining in soil at harvest provide inoculum for infection of new plants in the next growing season (54). Sclerotia are also formed on tubers and known as black scurf. These sclerotia provide means for $R$. solani to infect new crops when black scurf-infested tubers are used as seed $(18,55,66)$.

There have been few studies reporting on the interaction of $R$. solani with potato sprouts prior to emergence. The seminal studies of Richards (49) and Sanford (53) showed that the hyphae colonize densely a region just below the apex, which often kills the tip of the sprout (49). The plant responds with initiation of new sprouts from the base of the damaged one. In these new sprouts severe symptoms are usually not observed and they emerge successfully (53), which is unexpected considering that the pathogen has already infected plant tissues and presumably gained more energy and resources for further infection. It has previously been reported in bean (Phaseolus vulgaris L.) $(28,60,65,67)$ and rice plants (Oryza sativa L.) $(22,37)$ that infection with virulent isolates of $R$. solani activates many defense-related genes and results in production of pathogenesis-related proteins. Similar studies have not been reported on potato. Furthermore, in bean plants defense-related genes are induced systemically outside the infection site upon infection with $R$. solani (28). However, it is less known whether the observed induction of defense-related genes and proteins actually results in elevated levels of resistance to infection.

The aim of this study was to test whether infection with $R$. solani can activate defense-related genes and induce resistance systemically in potato sprouts. The sprouts were grown without light and in cool temperature to mimic the conditions in soil. Systemically induced changes in gene expression following primary infection were tested and challenge-inoculation carried out to verify whether the possibly observed differential expression of genes was associated with resistance to secondary infection with $R$. solani. 


\section{MATERIALS AND METHODS}

Inoculation. Strain RS11 of $R$. solani was recently isolated from potato in Finland and found to be one of the most virulent isolates among the 98 tested (38). Strain RS11 was grown on potato dextrose agar (PDA; Biokar, France) at room temperature (18 to $20^{\circ} \mathrm{C}$ ) in the dark for 5 days. $R$. solani grows vegetatively and does not form spores under the in vitro and in vivo growth conditions used in this study.

Certified healthy seed potatoes of cv. Saturna were obtained from The Finnish Seed Potato Center Ltd. (Tyrnävä, Finland). Dormant tubers were surface-sterilized with $1 \% \mathrm{NaOCl}$ for $5 \mathrm{~min}$ and rinsed four times ( 5 min each) with autoclaved tap water. Subsequently, they were placed in a dark room at $20^{\circ} \mathrm{C}$ for presprouting and protection from light. When sprout growth had started, tubers were moved to propagators and placed as a single layer on the bottom. The incubators were kept in a controlled growth cabinet (Sanyo Scientific, Bensenville, IL) at constant $18^{\circ} \mathrm{C}$ temperature without light. Growth of sprouts was periodi- cally checked under photosynthetically inactive black light $(365 \mathrm{~nm})$. When sprout length reached approximately $5.0 \mathrm{~cm}$, a collar made of $0.15-\mathrm{mm}$ thick low density polyethylene (LDPE) plastic (Pentti Laiho Ky, Nastola, Finland) was positioned to the middle of the sprout to isolate basal and apical portions (Fig. 1A). The basal portion of the sprout (1 sprout per tuber) was inoculated with RS11 by placing a plug ( $5 \mathrm{~mm}$ diameter) of PDA with the fungus on the tuber next to the sprout (Fig. 1A and B). Challenge inoculation of the apical portion was done $120 \mathrm{~h}$ after inoculation of the basal portion of the sprout. At this time, a PDA plug with the fungus was placed inside the plastic collar so that it was in contact with the sprout. Control sprouts had a plastic collar but were "mock-inoculated" with plugs of fungus-free PDA. Propagators were sprayed gently with tap water when needed to maintain humidity. All handling and observations (see later) were done under photosynthetically inactive light in a dark room where the growth cabinet was located (room temperature $18^{\circ} \mathrm{C}$ ).

Visualization of fungal growth. Fungal growth at the inoculated base of the sprout was monitored daily. Following chal-
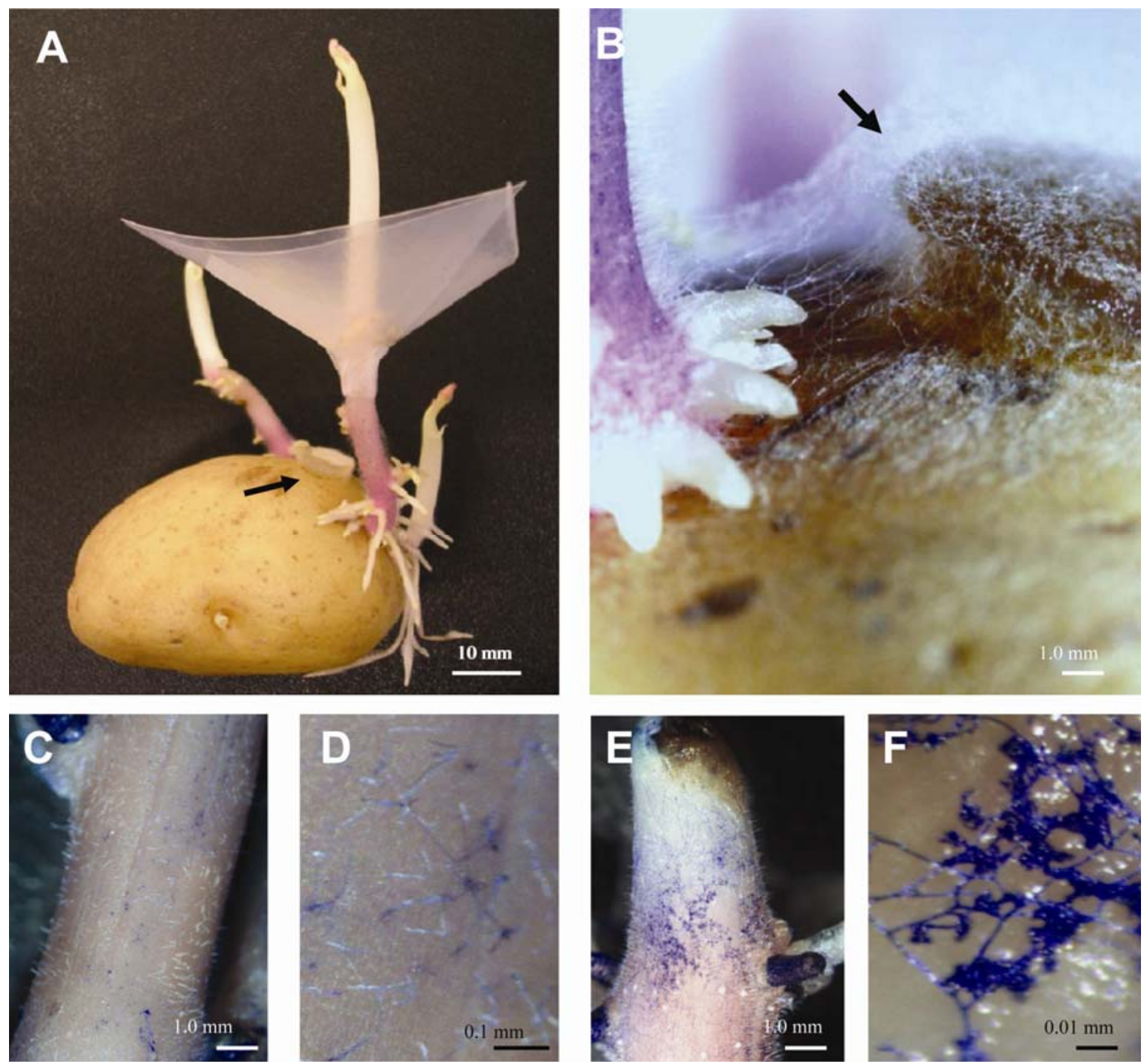





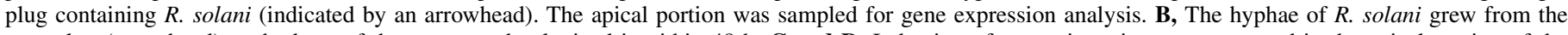

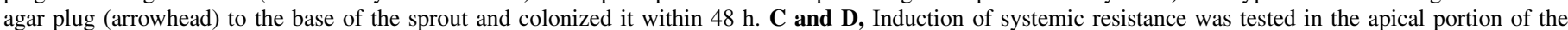

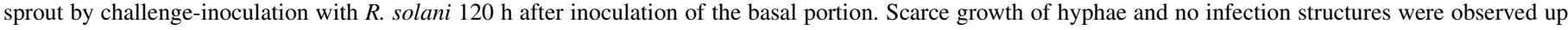



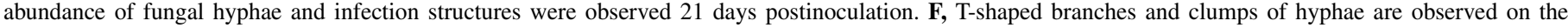

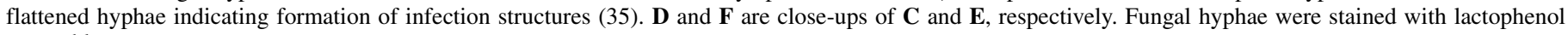
cotton blue. 
lenge-inoculation of the sprout top, the apical portion of the sprout was monitored at 3-day intervals, and hyphal growth and symptom development were observed for 21 days.

To observe the growth of hyphae in more detail, the sprout was stained in lactophenol cotton blue followed by rinsing with tap water. Stained sprouts were studied under Leica MZFLIII stereomicroscope (Leica Microsystems GmbH, Wetzlar, Germany) and photographed with digital camera using ViewFinder 1.0.135 and StudioLite 1.0.136 software (Pixera Corporation, Los Gatos, CA).

Extraction of RNA. From each treatment and time point (Fig. 2 ), the apical portions were sampled from five sprouts, pooled, snap-frozen in liquid nitrogen, and stored at $-80^{\circ} \mathrm{C}$ until RNA was isolated. The frozen material was crushed and ground under liquid nitrogen. Total RNA was extracted from $0.5 \mathrm{~g}$ of the homogenate using the Trizol reagent (14) and purified with Qiagen RNeasy Kit (Qiagen, Hilden, Germany) or by lithium chloride precipitation (52). Quality of RNA was verified spectrophotometrically.

Microarray analysis of gene expression. RNA samples were analyzed on microarray slides containing 11,412 validated potato cDNA clones according to the scheme presented in Figure 2. Samples i48hpi and i120hpi collected from the inoculated sprouts $48 \mathrm{~h}$ postinoculation (hpi) and $120 \mathrm{hpi}$, respectively, were analyzed against their mock inoculated counterparts, m48hpi and m120hpi, respectively. Additionally, sample m48hpi was analyzed against sample 0 which consisted of five sprouts sampled just before inoculation of other sprouts. To detect any changes in gene expression associated with growth and development of the sprouts during the experiment, samples $0, \mathrm{~m} 48 \mathrm{~h}$, and $\mathrm{m} 120 \mathrm{~h}$ were analyzed against each other. The entire experiment was carried out twice as explained previously, starting from surface sterilization and sprouting of tubers. In both experiments, hybridization of RNA samples was repeated using dye-swapping.

Extracted total RNA was amplified, repurified, and labeled with N-hydroxysuccinimide (NHS) ester dyes (Cy3 and Cy5) using Amino Allyl MessageAmp II aRNA Amplification Kit according the manufacturer's instructions (Ambion, TX). The method amplifies the mRNA and includes DNase treatment, which eliminates the influence of any possible trace amounts of DNA in

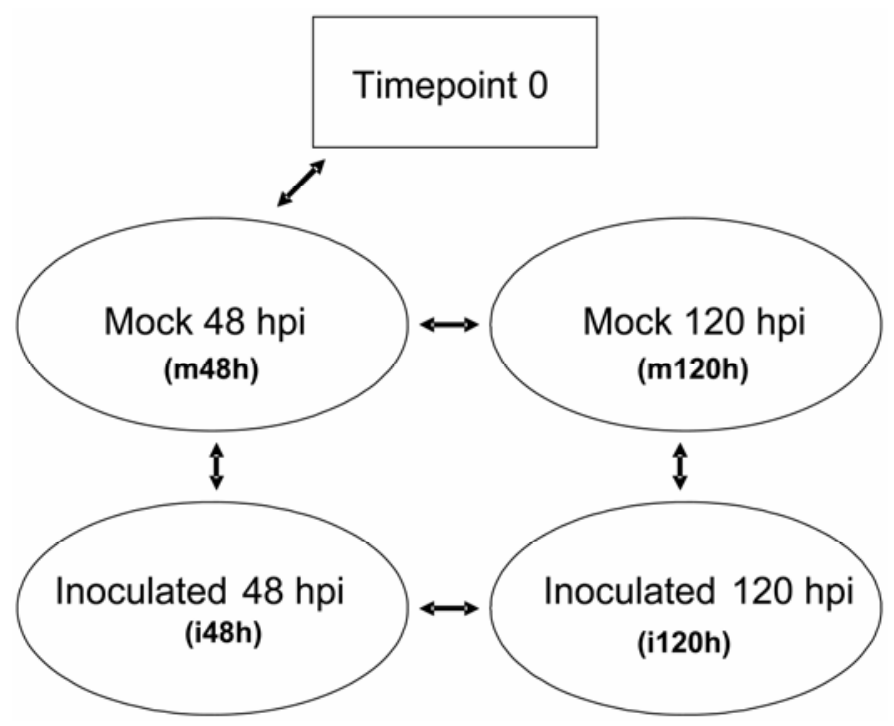

Fig. 2. The microarray hybridization scheme used for comparison of gene expression in the apical portion of potato sprouts. The basal portion of sprouts was inoculated with Rhizoctonia solani (i48h and i120h) or mock-inoculated ( $\mathrm{m} 48 \mathrm{~h}$ and $\mathrm{m} 120 \mathrm{~h})$ and samples collected 48 or 120 hours postinoculation (hpi), respectively. Each sample contained a pool of RNA from five sprouts. Samples at time point 0 were taken from five sprouts just before inoculation and mock-inoculation of other sprouts. Two independent biological experiments were carried out. the RNA samples extracted from plants. The labeled RNA ( $4 \mu \mathrm{g})$ was hybridized on TIGR Potato cDNA Array (10K version 4) obtained from the National Scientific Foundation's (NSF) Potato Functional Genomics Project (TIGR Solanaceae Genomics Resource, Rockville, MD). The hybridization scheme (pairs of samples compared on the same array) is presented in Figure 2. Hybridization and stringency washes were done according to the method developed by TIGR (30) with minor modifications. Microarray slides were incubated in prehybridization buffer $(5 \times$ sodium chloride-sodium citrate buffer (SSC), $0.1 \%$ sodium dodecyl sulfate (SDS), and $1 \%$ bovine serum albumin [BSA]) prewarmed to $42^{\circ} \mathrm{C}$ for $1 \mathrm{~h}$, rinsed five times in fresh deionized water, and dried in a slide centrifuge. The samples labeled with Cy3 and Cy5 were combined and spun for $5 \mathrm{~min}$ at 13,000 rpm in a table centrifuge. Supernatants were transferred to new Eppendorf tubes, $20 \mu \mathrm{l}$ of poly(dA) $(1 \mu \mathrm{g} / \mu \mathrm{l})$ and $1 \mu \mathrm{l}$ of herring sperm DNA were added, and samples were dried using vacuum centrifugation at $60^{\circ} \mathrm{C}$. Subsequently, $60 \mu \mathrm{l}$ of prewarmed $\left(42^{\circ} \mathrm{C}\right)$ hybridization buffer ( $50 \%$ formamide, $5 \times \mathrm{SSC}$, and $1 \%$ SDS) was added. Probes were denatured for $3 \mathrm{~min}$ at $95^{\circ} \mathrm{C}$ and placed on ice. Arrays were hybridized in a humid hybridization chamber at $42^{\circ} \mathrm{C}$ for $18 \mathrm{~h}$. Coverslips were removed on the following day by merging the slide into washing buffer I ( $1 \times$ SSC and $0.2 \%$ SDS). Stringency washing was done at room temperature with washing buffer I for $4 \mathrm{~min}$, washing buffer II $(0.1 \times \mathrm{SSC}$ and $0.2 \%$ SDS) for $10 \mathrm{~min}$, and twice with $0.1 \times \mathrm{SSC}$ for $10 \mathrm{~min}$. Finally, slides were washed twice with deionized water for $10 \mathrm{~min}$, dried in a slide centrifuge, and analyzed. Technical replications of hybridizations were done as described previously using dye-swapping.

Microarrays were scanned with GenePix 4200 AL (MDS Analytical Technologies, Toronto, Canada) using pixel resolution of $10 \mu \mathrm{m}$. Image analysis was carried out with GenePix Pro 6.0 software (Axon Instruments, Foster City, CA). Spot intensities were characterized by the mean of the foreground and median of the local background pixel values. Scanned and segmented images were visually checked and spots which showed anomalies in the hybridization were excluded from the analysis. Data normalization and statistical tests were computed using $\mathrm{R}$ software (47) with limma package (57). Spots whose foreground area was less than 30 pixels were not included in the analysis. Background-subtracted foreground signals were used for computing the ratios between $\mathrm{Cy} 5$ and $\mathrm{Cy} 3$ signals. Ratios were transformed into logarithmic domain and lowess normalization was applied for each slide. Normalized log-ratio values from duplicated spots were averaged on each array.

A linear model was fitted to the normalized log-ratio values. The model was parameterized so that there was a separate parameter for mock $(\mathrm{m})$ and induced (i) sample at two time points (48 and $120 \mathrm{~h}$ ); these conditions are denoted below as $\mathrm{m} 48 \mathrm{~h}$, $\mathrm{m} 120 \mathrm{~h}, \mathrm{i} 48 \mathrm{~h}$, and $\mathrm{i} 120 \mathrm{~h}$. Time point 0 was considered as a reference. Two arrays were used for measuring the difference between time point 0 and $\mathrm{m} 48 \mathrm{~h}$. Four parameter values were estimated for each gene, one for each condition of interest. Differences between the conditions were investigated using four contrasts (i) $\mathrm{m} 48 \mathrm{~h}$ versus $\mathrm{m} 120 \mathrm{~h}$, (ii) $\mathrm{m} 48 \mathrm{~h}$ versus $\mathrm{i} 48 \mathrm{~h}$, (iii) $\mathrm{m} 120 \mathrm{~h}$ versus $\mathrm{i} 120 \mathrm{~h}$, and (iv) i48h versus i120h (Fig. 2). Differentially expressed genes were detected by testing the contrasts for each gene and applying an empirical Bayes variance shrinkage method. False Discovery Rate (FDR) method was used for correcting the $P$ values due to multiple tests and the genes with FDR $<0.05$ were selected as differentially expressed. The microarray analyses complied with MIAME recommendations.

Genes with statistically significant changes in their expression level were grouped according to their known or predicted biological functions using the gene ontology listing (GO files) of TIGR and relevant research reports $(3,41,62)$. Overrepresented classes among differentially expressed genes were found by making the Fisher exact test for each class. 
Quantitative real-time polymerase chain reaction (qRTPCR). Gene expression was also tested by qRT-PCR. Primers for the genes to be tested were designed based on the sequences of the cDNAs spotted on the array (provided by TIGR) using Primer Express v2.0 software (Applied Biosystems, Foster City, CA). The potato actin gene was used as a reference. Specificity of primers was verified by alignment with the original Gene Bank sequence using standard Blast (National Center for Biotechnology Information [NCBI]). Expression levels of the potato actin gene (X55746.1) were tested in all samples to be used as a reference for data normalization. One microgram of total RNA was treated with DNaseI (Promega Corporation, Madison, WI) and reverse transcribed using Maloney murine leukemia virus (M-MLV) reverse transcriptase according the manufacturer's instructions (Promega). The cDNA was diluted five-fold for analysis. The reaction mixture was prepared and two-step qRT-PCR carried out with LightCycler 480 following instructions of the LightCycler 480 SYBR Green I Master Kit (Roche Diagnostics GmbH, Mannheim, Germany). The PCR program included 5 min preincubation at $95^{\circ} \mathrm{C}$, followed by 45 cycles of $10 \mathrm{~s}$ at $95^{\circ} \mathrm{C}, 5 \mathrm{~s}$ at $60^{\circ} \mathrm{C}$, and $5 \mathrm{~s}$ at $72^{\circ} \mathrm{C}$. A melting curve analysis was made at the end of the program by elevating the temperature of the denatured $\left(5 \mathrm{~min}\right.$ at $95^{\circ} \mathrm{C}$ ) product from 65 to $97^{\circ} \mathrm{C}$.

Expression fold changes of the analyzed genes were calculated with E-method (Roche Applied Sciences) according to the efficiencies of clone-specific primers that were designed based on the potato cDNA sequence data available from TIGR. The qRTPCR analysis of each sample included three technical replicates for each gene. The fold change for each gene was computed as an average of three qRT-PCR runs (technical replicates).

Results from the two types of gene expression analysis were compared by plotting the fold change values of genes obtained by qRT-PCR as a function of fold change values of probe intensities obtained by the microarray analysis.

\section{RESULTS}

Differential expression of genes. Changes in gene expression were assessed in the apical portions of potato sprouts following previous inoculation of the basal portion with the highly virulent isolate of $R$. solani (RS11, AG-3; 38). The basal and apical portions of the sprout were isolated with a soft but tight plastic collar (Fig. 1A) to prevent growth of mycelia from the basal portion to the apical portion that was analyzed. The method of isolation worked well and no hyphae were detected in the apical portion of the sprouts at the time of sampling, as observed under microscope following staining with lactophenol cotton blue (data not shown).
The first sampling of the apical portion of five sprouts was made at 48 hpi when $R$. solani was colonizing the surface of the basal portion of the sprout but had not yet formed detectable infection structures (Fig. 1B). A total of 77 genes appeared to be upregulated and 45 genes showed reduced expression when the pooled RNA of inoculated sprouts (i48h) was compared with mock-inoculated sprouts $(\mathrm{m} 48 \mathrm{~h})$ on microarray slides containing 11,412 validated potato cDNA clones (Table 1). The second sampling of the apical portions of additional five sprouts was made 120 hpi when T-shaped branches were observed on the flattened hyphae, and clumps of hyphae were formed on the basal portion of the sprout, which indicated formation of infection structures (35). At this time, expression of 453 and 326 genes was found to be upregulated and down-regulated, respectively, in the apical portion of inoculated sprouts (Table 1). Samples taken 48 and 120 hpi were directly compared on the array to determine how expression differed in inoculated sprouts between these time points (Fig. 2). Of the 77 genes that were upregulated at $48 \mathrm{hpi}$, 76 genes were still upregulated at $120 \mathrm{hpi}$. Phenylalanine ammonialyase (PAL) gene was the only one upregulated at $48 \mathrm{hpi}$ that no longer showed significantly higher expression at $120 \mathrm{hpi}$ compared with the controls. These results were nearly identical for two independent experiments, consistent with the carefully standardized growth conditions, treatments, and other procedures.

To verify that changes in gene expression patterns were not influenced by physiological age of the plant during the experiment, samples from mock-inoculated sprouts were compared (0 versus $\mathrm{m} 48 \mathrm{~h}$, and $\mathrm{m} 48 \mathrm{~h}$ versus $\mathrm{m} 120 \mathrm{~h}$; Fig. 2). Just a few genes exhibited a slightly altered expression level over the $120 \mathrm{~h}$, but none of these differences were statistically significant (data not shown). Therefore, it was concluded that physiological changes associated with growth and development of the sprout per se did not influence gene expression patterns within the time needed for the experiment.

Genes with statistically significant changes in expression levels (FDR $<0.05$ ) were grouped according to their known or predicted biological function (gene ontology [GO]). Overrepresented classes among differentially expressed genes were detected using the Fisher exact test where a small $P$ value of a gene class indicates a potentially meaningful biological role for that GO class. The test indicated nine gene ontology classes with $P<0.05$ (GO:0009536, GO:0009579, GO:0009607, GO:0015979, GO:0030154, GO:0030246, GO:0016049, GO:0016740, and GO:0019825; codes according to the TIGR database). Additional sources $(3,41,62)$ were used to make the final classification of the genes (Table 1). A total of 27 and 79 genes showing upregulated expression in the inoculated sprouts at 48 and $120 \mathrm{hpi}$, respectively, were classified to the category of disease defense and

TABLE 1. The number and gene ontology-based categorization of differentially expressed genes in the uninoculated apical portion of potato sprouts following inoculation of the basal portion

\begin{tabular}{|c|c|c|c|c|}
\hline \multirow[b]{3}{*}{ Category } & \multicolumn{4}{|c|}{ Sampling time $\mathrm{a}^{\mathrm{a}}$} \\
\hline & \multicolumn{2}{|c|}{48 hpi } & \multicolumn{2}{|c|}{$120 \mathrm{hpi}$} \\
\hline & Induced & Suppressed & Induced & Suppressed \\
\hline Energy & 1 & 3 & 20 & 11 \\
\hline Disease defense and cell rescue & 26 & 6 & 79 & 24 \\
\hline Replication and transcription & 7 & 2 & 43 & 35 \\
\hline Signaling & 4 & 2 & 29 & 29 \\
\hline Protein synthesis, modification and destination & 1 & 0 & 20 & 11 \\
\hline Classification not clear/function unknown & 15 & 10 & 119 & 69 \\
\hline Total no. & 76 & 45 & 453 & 326 \\
\hline
\end{tabular}

a The apical parts of sprouts were sampled $48 \mathrm{~h}$ postinoculation (hpi) and $120 \mathrm{hpi}$ of the basal portion with Rhizoctonia solani and gene expression compared with mock-inoculated sprouts at the same time points using microarray analysis. Only genes whose differential expression was consistently observed in two independent experiments are included (false discovery rate $<0.05$ ). 
cell response (Table 1). With the exception of PAL (mentioned previously), the 27 genes falling into this category and detected at $48 \mathrm{hpi}$ remained significantly upregulated at $120 \mathrm{hpi}$, along with 53 additional defense-related genes. The detected defense-related genes encoded chitin-hydrolyzing enzymes such as acidic chitinases of classes II, III, and IV, members of the pathogenesisrelated (PR) protein groups 1, 2, 3, 4, 8, 9, 10, and 11 (including $1,3-\beta$-glucanase and lignin-catalyzing peroxidases), osmotin-like proteins, defense-associated signaling kinases, host protein protecting substances, and enzymes leading to phytoalexin accumulation (Table 1).

A total of 24 genes whose expression was systemically upregulated in the inoculated sprouts and whose involvement in pathogen defense has been implicated in previous studies were chosen for analysis with qRT-PCR. The samples from both time points of the two experiments were analyzed (Table 2). Data were normalized using the expression levels of the actin gene, which remained constant between the samples, time points, and experiments (threshold $23.24 \pm 0.44$ cycles; $n=24$ ).

Data from qRT-PCR and microarray analyses were compared by plotting the fold change values obtained in qRT-PCR as a function of the fold change values of signal intensities obtained in the microarray analysis (Fig. 3). The results from these analyses were consistent for all but two tested genes. Differential expression of one gene was detected only by microarray analysis and it was omitted. On the other hand, the expression fold change of a putative class IV chitinase gene (clone STMFB59; Table 2) was considerably higher in the microarray analysis than qRT-PCR. Therefore, the two values for this gene were not considered while fitting a regression line to the data (Fig. 3). The slope of the line was 1.5 indicating that qRT-PCR was more sensitive than microarray analysis in detecting differences of gene expression. The 24 genes for which upregulation was detected with both methods are listed in Table 2.

Systemic induction of resistance. Since sampling for gene expression required removal of the apical portion of the sprout, two experiments, additional to those for microarray and qRT-PCR analyses, were carried out under identical growing conditions to monitor possible induction of systemic resistance to $R$. solani up to 21 days post-challenge-inoculation (dpi). The aim of these additional experiments was to test whether the observed changes in the transcriptome in the apical portion of sprouts were associated with detectable levels of resistance to $R$. solani. The upper part of the sprout above the plastic collar was challenge-inocu-

TABLE 2. Quantitative real-time reverse-transcription polymerase chain reaction analysis of systemic induction of 24 defense-related genes in the uninoculated apical portion of potato sprouts following inoculation of the basal portion in two experiments (I and II)

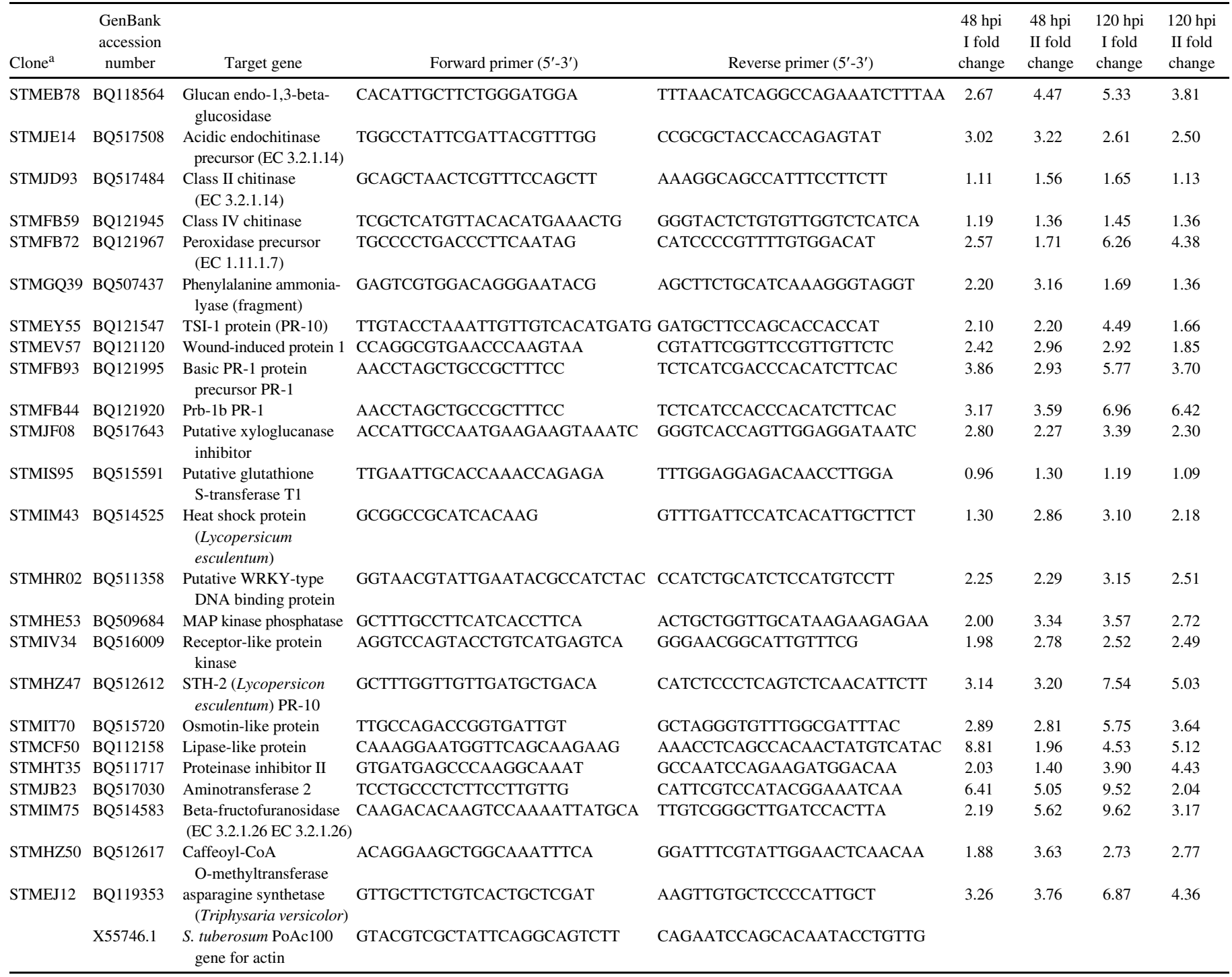

\footnotetext{
${ }^{a}$ Clone names are according to the TIGR-SGR database. Fold changes of gene expression are means of three technical replicates and presented relative to mock-inoculated sprouts. The potato actin gene was used as an endogenous control. At 48 and $120 \mathrm{~h}$ postinoculation (hpi), the apical portion of sprouts sampled at 48 and 120 hpi of the basal part, respectively. I and II, two independent biological experiments.
} 
lated with $R$. solani $120 \mathrm{~h}$ after inoculation of the lower part (Fig. $1 \mathrm{~A}$ and $\mathrm{B})$. The results of both experiments consistently revealed high levels of systemically induced resistance to secondary infection with $R$. solani. It was exhibited as a strong inhibition of hyphal growth and negligible formation of infection structures on 14 of the 16 sprouts tested $(87.5 \%)$, as shown in Figure 1 (C and D) following staining of the hyphae with lactophenol cotton blue. However, on two sprouts hyphal growth was more abundant. In contrast, when the lower part was not previously inoculated, the upper part of the sprout remained susceptible to infection. In these controls, the upper part of 13 of the 16 sprouts $(81.3 \%)$ was heavily colonized by the mycelium of $R$. solani and an abundance of hyphal clumps indicated efficient formation of infection structures (Fig. 1E and F). Fungal growth was particularly strong in a zone 3 to $7 \mathrm{~mm}$ below the sprout tip and on the emerging laterally growing stolons initiated from this zone (Fig. 1E), which was consistent with the pioneering studies and photographic documentation by Richards (49). He found that $R$. solani initially attacked "the sinus or re-entrant angle of the hook-shaped bud, at which point considerable quantities of mycelium was collected."

\section{DISCUSSION}

The results of this study show that potato sprouts developing without access to photosynthetically active light can respond to $R$. solani infection by induction of a systemic defense response. This induction correlates with significant reduction of subsequent infection by the same pathogen. Systemic induction of resistance was associated at the molecular level with induction of a large number of defense-related genes as soon as 48 and 120 hpi. At $48 \mathrm{hpi}$, the base of the sprout was colonized by $R$. solani but no apparent infection structures were detected. However, systemic induction of defense-related genes at this early stage of the infection process was observed, which showed that potato sprouts are capable of recognizing the invading hyphae of $R$. solani quite sensitively and quickly. To our knowledge, induction of efficient pathogen defense has not been characterized previously in the subterranean parts of the potato plant, including sprouts prior to emergence. This study also provides first indications of the potato genes that respond to infection with virulent strains of $R$. solani, an important pathogen damaging potato crops in all production areas $(38,68$, and references therein).

The results of this study might help to explain a long-known phenomenon characteristic of the first phase of disease caused by $R$. solani on potato. After initial infection and damage of the first sprouts, new sprouts suffer much less from infection of $R$. solani (49). As noted by Sanford (53), "these secondary sprouts appear to possess a remarkable degree of resistance, notwithstanding, the primary sprouts were very susceptible and severely attacked under apparently identical conditions." Many authors have noted the phenomenon but the mechanism behind it has received less attention $(4,31,48,54,70)$. In the present study, we did not test induced resistance and defense gene expression in the secondary sprouts, and our experimental layout does not therefore fully correspond to the normal infection process on developing potato plants. However, the experiments mimicked seedborne infection and the data showed that induction of defense begins early, prior to development of visible infection structures and damage on sprouts. It may be hypothesized that under normal growth conditions the speed of growth of $R$. solani towards the sprout tip may exceed the speed at which sufficiently strong defense is induced in the sprouts that get infected first, which allows $R$. solani to cause heavy infection and death of the tip in the initially infected sprouts. In the experiments of the present study, we could observe that the initially infected sprout responds with systemic induction of defense because the growth of $R$. solani to the apical portion of the sprout was physically prevented. The possibility therefore remains that the level of defense is elevated in the secondary sprouts that emerge from the basal portion of the initially infected sprout. The secondary sprouts may be primed for defense and/or express higher levels of resistance than the primary sprout from the beginning of their development and hence escape the disease caused by $R$. solani for this reason. This hypothesis needs to be tested in future studies.

It is remarkable that significant resistance to $R$. solani developed in potato sprouts that were not exposed to photosynthetically active light. The different hypotheses explaining how light affects pathogen or herbivore resistance make a common presumption that allocation to defense versus growth and storage is the function of competition between these three end-points for the limited resources (50). Activation of defense involving a large number of genes, as observed in this study, should therefore be constrained for resources and rendered less efficient in lack of light (44). Prior to emergence, the seed tuber is the only source of energy for sprouts, whereas they can obtain additional energy via photosynthesis after emergence. This idea is supported by the fact that development of stem canker ceases at stem bases beneath the soil following plant emergence $(32,56,63,70)$. However, the results of this study indicate that potato sprouts are able to defend against $R$. solani also without light. The sprouts can quickly sense invasion by $R$. solani, mobilize resources from the seed tuber, and hence, activate an efficient defense response before they obtain additional energy via photosynthesis. It seems that potato is wellequipped and adapted to combat hostile invaders in the underground parts of the plant even in absence of light and active photosynthesis.

A total of 779 genes in potato sprouts showed statistically significant, altered expression in the apical, noninfected portion 5 days (120 hpi) after inoculation of the basal portion. These data indicate efficient systemic signaling in the sprouts. The number of differentially expressed genes might have been much larger than detected in this study because the TIGR $10 \mathrm{~K}$ potato microarray

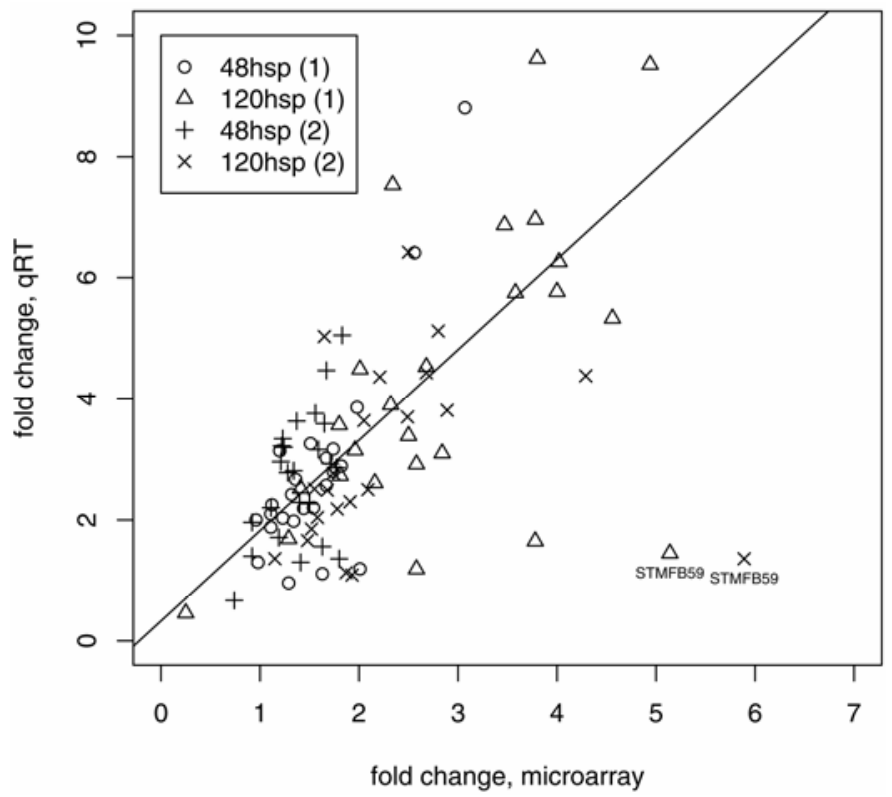

Fig. 3. Comparison of the results of microarray analysis and quantitative realtime reverse transcriptase polymerase chain reaction (qRT-PCR) analysis on systemic induction of 24 defense-related genes in potato sprouts. The fold change values obtained in qRT-PCR were plotted as a function of the fold change values of signal intensities obtained in the microarray analysis for 24 systemically induced defense-related genes analyzed at two time points (48 and $120 \mathrm{~h}$ postinoculation) in the two independent biological experiments 1 and 2. Results from the two analyses were consistent except for a class IV chitinase gene (STMFB59) that showed a much higher fold change in microarray analysis than qRT-PCR. It was excluded prior to fitting the illustrated regression line to the data. 
contains probes for approximately one-third of the total estimated number of potato genes. The upregulated transcripts mainly belong to the diverse groups of genes that are also activated by other pathogens in potato and pathogen infection in other plant species. Examples include potato infected with Phytophthora infestans, Pectobacter carotovorum (Erwinia carotovora), or viruses $(23,42,45,51,62)$, other species of Solanaceae infected with a wide range of pathogens (24), rice challenged with $R$. solani (68), and canola (74), and wheat (26) infected with many economical important fungal pathogens. Products of these induced genes prevent pathogen invasion and damage of plant tissues by strengthening cell walls, generating reactive oxygen species and other molecules for signaling and with direct antimicrobial effects, and producing phytoalexins and lytic enzymes that can destroy the intruder $(24,43)$.

A large number of the activated defense-related genes observed in this study encode chitin-hydrolyzing enzymes belonging to the PR protein groups $3,4,8$, and 11 (64) that have no endogenous substrates in higher plants (1). According to the microarray data, six chitinase genes were activated $48 \mathrm{hpi}$ and all continued to show high levels of expression until $120 \mathrm{hpi}$, which suggested an important role in the response to $R$. solani. Several chitinase isoforms have been identified in plants (20). They are induced during invasion of many fungi and presumed to play an active role in defense against necrotrophic fungal pathogens (64). Chitinases can break down fungal cell walls by catalyzing hydrolysis of chitin, but the specific hydrolytic activity on colloidal chitin may vary within a range of two orders of magnitude depending on the form of chitinase and substrate (12). The ability of purified chitinase to digest cell walls of $R$. solani has been demonstrated in vitro and in vivo $(6,7)$.

Systemic activation of the $1,3-\beta$-glucanase (PR-2) gene was observed in potato sprouts concomitant with induction of the acidic chitinases belonging to classes 2, 3 (acidic endochitinase precursor), and 4 defined by van Loon and van Strien (64). Previously, pronounced elevation of the enzymatic activity levels of chitinase and 1,3- $\beta$-glucanase has been detected in potato leaves infected with $P$. infestans (36). Many studies indicate that protection against $R$. solani is enhanced by co-expression of chitinases and the 1,3- $\beta$-glucanases providing another important fungal cell wall hydrolyzing enzyme activity (46). Concomitant expression of osmotin-like proteins with chitinases was also observed in potato sprouts in this study. In a previous study on potato suspension cultures, co-expression of these proteins was hypothesized to enhance host defense (61) because overexpression of osmotins may delay symptom development following infection of potato plants with $P$. infestans (39). Co-activation and synergistic action of the different enzymes and defense-related proteins may be needed to speed up destruction of the hyphae of $R$. solani. The newly synthesized chitin in the cell walls of young hyphae is more sensitive to enzymatic degradation (40) and defense is hence best achieved by early actions against the young hyphae. This hypothesis is consistent with the observation that little fungal growth was observed in the apical portion of potato sprout expressing systemically induced resistance.

On the other hand, $R$. solani produces polygalacturonase and various pectin methylesterases to degrade plant cell walls $(8,33)$. The resultant degradation products can act as elicitors and induce expression and systemic accumulation of defense-associated molecules, such as the salicylic acid (SA) dependent basic PR-1 protein, defense associated signaling kinases, lignin catalyzing peroxidases (PR-9), host protein protecting substances, and enzymes for phytoalexin accumulation including PAL. Induction of the respective genes was detected in potato sprouts infected with $R$. solani in this study. Accumulation of transcripts for PAL was high at 48 hpi but no longer significantly different from controls at $120 \mathrm{hpi}$, which indicates that induction of the phenylpropanoid pathway took place quickly after infection. In bean plants, infection with pathogenic $R$. solani causes strong systemic induction of PAL and another defense-related enzyme, 1,3- $\beta$-Dglucanase (67). The glucan endo-1,3- $\beta$-D-glucosidase activity that was detected at the mRNA transcript level also in this study catalyses the hydrolysis of $1,3-\beta-D$-glucosidic linkages in $1,3-\beta-$ $D$-glucans of the fungal cell walls. The released $\alpha$-1,3-glucans induce host defense, including elevated protection against $R$. solani $(71,72)$. Since induction of these PR-proteins is SAdependent, and SA can be used to induce resistance to $R$. solani in cowpea (19), SA probably plays an important role also in the systemic activation of defense in the potato sprouts infected with $R$. solani. Activation of SA-dependent PR proteins may also occur due to abiotic stress (9), but this could be excluded in the case of this study because no significant activation was observed in the control plants.

Many differentially expressed defense-related genes detected in potato sprouts in this study have been shown by previous authors to provide protection against $R$. solani when over-expressed in transgenic plants. Constitutive expression of chitinases, 1,3- $\beta$-glucanases, and ribosome inactivating proteins from the respective transgenes, alone or in different combinations, has improved resistance to $R$. solani in potato and other important crop plants, including rice, canola, tobacco, and cucumber $(11,21,40,46,69)$. The protective effects have been observed as reduced incidence of infection, lower seedling mortality, and alleviated severity of symptoms.

Besides their intrinsic scientific value, the data of this study encourage development of new means for the control of $R$. solani in potato. At present, the control relies on the use of healthy seed potatoes, dressing of black scurf-infested seed lots with chemical fungicides, and practicing crop rotation to avoid build-up of inoculum in soil during continuous potato cultivation in the same field (59). As it is now known that potato sprouts can be induced for resistance to $R$. solani before emergence, activation of resistance might be further exploited using biocontrol agents (10 and references therein). The observed induction of defense-related genes can be achieved following inoculation of plants with nonpathogenic binucleate Rhizoctonia or hypovirulent isolates of $R$. solani. The "priming" of defense by the nonpathogenic isolates is one key for their potential in biological control of pathogens $(34,73)$. Soilborne nonpathogenic binucleate Rhizoctonia isolates colonize potato plants in the field (38) and can be used for biocontrol purposes in potato $(71,72)$. In tomato, hypovirulent $R$. solani can induce systemic defense and alleviate the symptoms caused by virulent $R$. solani (15).

Responses of plants are initially rather similar in the compatible and incompatible interactions with microbes (24). Defense responses are activated also in roots invaded by arbuscular mycorrhizal (AM) fungi, although the opposite may be experienced in some cases (27). In bean and alfalfa, the responses induced by AM fungi have not been sufficient to protect the roots against infection with $R$. solani $(27,28)$, whereas in potato AM fungi can protect the plants against $R$. solani and increase yields under experimental conditions (75). Whether the mechanism is associated with resistance induction, competition, or other mechanisms has not been reported. In low input production systems AM fungi are pivotal for supplying potato plants with phosphorous (25), which in turn is of high demand for ensuring good processing quality of tubers and high starch yields (13). Therefore, future studies should develop applicable means for the use of living biocontrol agents or other resistance-inducing elicitors for early priming of defense in potato sprouts and protection of them against the first phase of disease caused by $R$. solani.

\section{ACKNOWLEDGMENTS}

We thank A. Vuorinen for advice with qRT-PCR and microarray analysis and to P. Ahvenniemi for fruitful discussions. Financial support 
from the Ministry of Agriculture and Forestry (grant 4655/501/2003), University of Helsinki, Viikki Graduate School of Biosciences and the following Finnish companies and advisory organizations is gratefully acknowledged: Berner, Chips, Finnamyl, Finnish Horticultural Products Society, Finnish Seed Potato Centre, HG Vilper, Jepuan Peruna, Järviseudun Peruna, Kemira GrowHow, Kesko, Krafts Food, MTT AgriFood Finland North Ostrobothnian Research Station, Northern Seed Potato, Potwell, ProAgria Association of Rural Advisory Centers, ProAgria Rural Advisory Centre of Oulu, Ravintoraisio-Ruokaperuna, Ruokakesko, Saarioinen, and Solanum.

\section{LITERATURE CITED}

1. Ancillo, G., Witte, B., Schmelzer, E., and Kombrink, E. 1999. A distinct member of the basic (Class I) chitinase gene family in potato is specifically expressed in epidermal cells. Plant Mol. Biol. 39:1137-1151.

2. Anderson, N. A. 1982. Genetics and pathology of Rhizoctonia solani. Annu. Rev. Phytopathol. 20:329-347.

3. Ashburner, M., Ball, C. A., Blake, J. A., Botstein, D., Butler, H., Cherry, J. M., Davis, A. P., Dolinski, K., Dwight, S. S., Eppig, J. T., Harris, M. A., Hill, D. P., Issel-Tarver, L., Kasarskis, A., Lewis, S., Matese, J. C., Richardson, J. E., Ringwald, M., Rubin, G. M., and Sherlock, G. 2000. Gene Ontology: Tool for the unification of biology. Nat. Genet. 25:25-29.

4. Baker, K. F. 1970. Types of Rhizoctonia disease and their occurrence. Pages 125-148 in: Rhizoctonia solani: Biology and Pathology. J. R. Parmeter, ed. University of California Press, Berkeley, CA.

5. Banville, G. J., Carling, D. E., and Otrysko, B. E. 1996. Rhizoctonia diseases on potato. Pages 321-330 in: Rhizoctonia Species: Taxonomy, Molecular Biology, Ecology, Pathology and Disease Control. B. Sneh, S. Jabaji-Hare, S. Neate, and G. Dijst, eds. Kluwer Academic Publishers, Dordrecht, The Netherlands.

6. Banhamou, N., Broglie, K., Broglie, R., and Chet, I. 1993. Antifungal effect of bean endochitinase on Rhizoctonia solani: Ultrastructural changes and cytochemical aspects of chitin breakdown. Can. J. Microbiol. 39:318-328.

7. Banhamou, N., Broglie, K., Chet, I., and Broglie, R. 1993. Cytology of infection of 35S-bean chitinase transgenic canola plants by Rhizoctonia solani. Cytolochemical aspects of chitin breakdown in vivo. Plant J. 4:295-305.

8. Bateman, D. F. 1963. Pectolytic activities of culture filtrates of Rhizoctonia solani and extracts of Rhizoctonia-infected tissues of bean. Phytopathology 53:197-204.

9. Brederode, F. T., Linthorst, H. J., and Bol, J. F. 1991. Differential induction of acquired resistance and PR gene expression in tobacco by virus infection, ethephon treatment, UV light and wounding. Plant Mol. Biol. 17:1117-11125.

10. Brewer, M. T., and Larkin, R. P. 2005. Efficacy of several potential biocontrol organisms against Rhizoctonia solani on potato. Crop Prot. 24:939-950.

11. Broglie, K., Chet, I., Holliday, M., Cressman, R., Biddle, P., Knowlton, S., Mauvais, C. J., and Broglie, R. 1991. Transgenic plants with enhanced resistance to the fungal pathogen Rhizoctonia solani. Science 254:11941197.

12. Brunner, F., Stintzi, A., Fritig, B., and Legrand, M. 1998. Substrate specificities of tobacco chitinases. Plant J. 14:225-234.

13. Burton, W. G. 1989. The Potato, 3rd ed. Longman Scientific \& Technical, NY.

14. Caldo, R. A., Nettleton, D., and Wise, R. P. 2004. Interaction-dependent gene expression in Mla-specified response to barley powdery mildew. Plant Cell 16:2514-28.

15. Cardinale, F., Ferraris, L., Valentino, D., and Tamietti, G. 2006. Induction of systemic resistance by a hypovirulent Rhizoctonia solani isolate in tomato. Physiol. Mol. Plant Pathol. 69:160-171.

16. Carling, D. E., Baird, R. E., Gitaitis, R. D., Brainard, K. A., and Kuninaga, S. 2002. Characterization of AG-13, a newly reported anastomosis group of Rhizoctonia solani. Phytopathology 92:893-899.

17. Carling, D. E., and Leiner, R. H. 1986. Isolation and characterization of Rhizoctonia solani and binucleate $R$. solani-like fungi from aerial stems and subterranean organs of potato plants. Phytopathology 76:725-729.

18. Carling, D. E., Leiner, R. H., and Westphale, P. C. 1989. Symptoms, signs and yield reduction associated with Rhizoctonia disease of potato induced by tuber-borne inoculum of Rhizoctonia solani AG3. Am. Potato J. 66:693-701.

19. Chandra, A., Saxena, R., Dubey, A., and Saxena, P. 2007. Change in phenylalanine ammonia lyase activity and isozyme patterns of polyphenol oxidase and peroxidase by salicylic acid leading to enhance resistance in cowpea against Rhizoctonia solani. Acta Physiol. Plant. 29:361-367.
20. Collinge, D. B., Kragh, K. M., Mikkelsen, J. D., Nielsen, K. K., Rasmussen, U., and Vlad, K. 1993. Plant chitinases. Plant J. 3:31-40.

21. Datta, K., Velazhahan, R., Oliva, N., Ona, I., Mew, T., Khush, G. S., Muthukrishnan, S., and Datta, S. H. 1999. Over-expression of the cloned rice thaumatin-like protein (PR-5) gene in transgenic rice plants enhances environmental friendly resistance to Rhizoctonia solani causing sheath blight disease. Theor. Appl. Genet. 98:1138-1145.

22. Deborah, S. D., Palaniswami, A., Vidhyasekaran, P., and Velazhahah, R. 2001. Time-course study of the induction of defence enzymes, phenolics and lignin in rice in response to infection by pathogen and non-pathogen. J. Plant Dis. Prot. 108:204-216.

23. Dellagi, A., Heilbronn, J., Avrova, A. O., Montesano, M., Palva, E. T., Stewart, H. E., Toth, I. K., Cooke, D. E. L., Lyon, G. R., and Birch, P. R. J. 2000. Potato gene encoding a WRKY-like transcription factor is induced in interactions with Erwinia carotovora subs. atroceptica and Phytophthora infestans and is coregulated with Class I endochitinase expression. Mol. Plant-Microbe Interact. 13:1092-1101.

24. Desender, S., Andrivon, D., and Val, F. 2007. Microreview - Activation of defence reactions in Solanaceae: Where is the specificity? Cell. Microbiol. 9:21-30.

25. Drissner, D., Kunze, G., Callewaert, N., Gehrig, P., Tamasloukht, M., Boller, T., Felix, G., Amrhein, N., and Bucher, M. 2007. Lysophosphatidylcholine is a signal in the arbuscular mycorrhizal symbiosis. Science 318:265-268

26. Golkari, S., Gilbert, J., Prasher, S., and Procunier, J. D. 2007. Microarray analysis of Fusarium graminearum-induced wheat genes: Identification of organ-specific and differentially expressed genes. Plant Biotech. J. 5:38-49.

27. Guenoune, D., Galili, S., Phillips, D. A., Volpin, H., Chet, I., Okon, Y., and Kapulnik, Y. 2001. The defense response elicited by the pathogen Rhizoctonia solani is suppressed by colonization of the AM-fungus Glomus intraradices. Plant Sci. 160:925-932.

28. Guillon, C., St-Arnaud, M., Hamel, C., and Jabaji-Hare, S. H. 2002. Differential and systemic alteration of defence-related gene transcript levels in mycorrhizal bean plants infected with Rhizoctonia solani. Can. J. Bot. 80:305-315.

29. Gvozdeva, E. I., Volotskaya, A. V., Sof in, A. V., Kudryavtseva, N. N., Revina, T. A., and Valueva, T. A. 2006. Interaction of proteinases secreted by fungal pathogen Rhizoctonia solani with natural proteinase inhibitors produced by plants. Appl. Biochem. Microbiol. 42:502-507.

30. Hegde, P., Qi, R., Abernathy, R., Gay, C., Dharap, S., Gaspard, R., EarleHughes, J., Snesrud, E., Lee, N. H., and Quackenbush, J. 2000. A concise guide to cDNA microarray analysis-II. Biotechniques 29:548-562.

31. Hide, G. A., and Cayley, G. R. 1982. Chemical techniques for control of stem canker and black scurf (Rhizoctonia solani) disease of potatoes. Ann. Appl. Biol. 100:105-116.

32. Hide, G. A., Read, P. J., and Sandison, J. P. 1985. Stem canker (Rhizoctonia solani) of maincrop potatoes. I. Development of the disease. Ann. Appl. Biol. 106:413-422.

33. Jabaji-Hare, S., Chamberland, H., and Charest, P. M. 1999. Cell wall alterations in hypocotyls of bean seedlings protected from Rhizoctonia stem canker by binucleate Rhizoctonia isolate. Mycol. Res. 103:1035-1043.

34. Jung, W. J., Mabood, F., Kim, T. H., and Smith, D. L. 2007. Induction of pathogenesis related proteins during biocontrol of Rhizoctonia solani with Pseudomonas aureofaciens in soybean (Glycine max L. Merr.) plants. BioControl 52:895-904.

35. Keijer, J. 1996. The initial steps of the infection process in Rhizoctonia solani. Pages 149-162 in: Rhizoctonia Species: Taxonomy, Molecular Biology, Ecology, Pathology and Disease Control. B. Sneh, S. Jabaji Hare, S. Neate, and G. Dijst, eds. Kluwer Academic Publishers, Dordrecht, The Netherlands.

36. Kombrink, E., Schröder, M., and Hahlbrock, K. 1988. Several 'pathogenesis-related' proteins in potato are 1,3- $\beta$-glucanases and chitinases. Proc. Natl. Acad. Sci. USA 85:782-786.

37. Lee, J., Bricker, T. M., Lefevre, M., Pinson, S. R. M., and Oard, J. H. 2006. Proteomic and genetic approaches to identifying defense-related proteins in rice challenged with fungal pathogen Rhizoctonia solani. Mol. Plant Pathol. 7:405-416.

38. Lehtonen, M. J., Ahvenniemi, P. M., Wilson, P. S., German-Kinnari, M., and Valkonen, J. P. T. 2008. Biological diversity of Rhizoctonia solani (AG-3) in a northern potato cultivation environment in Finland. Plant Pathol. 57:141-151.

39. Liu, D., Raghothama, K. G., Hasegeva, P. M., and Bressan, R. A. 1994. Osmotin overexpression in potato delays development of disease symptoms. Proc. Natl. Acad. Sci. USA 91:1888-1892.

40. Lorito, M., Woo, S. L., Fernandez, I., Colucci, G., Harman, G. E., PintorToro, J., Filippone, E., Muccifora, S., Lawrence, C. B., Zoina, A., Tuzun, S., and Scala, F. 1998. Genes from mycoparasitic fungi as a source for improving plant resistance to fungal pathogens. Proc. Natl. Acad. Sci. USA 95:7860-7865. 
41. Mahalingam, R., Gomez-Buitrago, A. M., Eckardt, N., Shah, N., GuevaraGarcia, A., Day, P., Raina, R., and Fedoroff, N. 2003. Characterizing the stress/defence transcriptome of Arabidopsis. Genome Biol. 4:R20.

42. Montesano, M., Brader, G., Ponce de León, I., and Palva, E. T. 2005. Multiple defence signals induced by Erwinia carotovora sp. carotovora elicitors in potato. Mol. Plant Pathol. 6:541-549.

43. Nürnberg, T., Brunner, F., Kemmerling, B., and Piater, L. 2004. Innate immunity in plants and animals: Striking similarities and obvious differences. Immunol. Rev. 198:249-266.

44. Pennypacker, B. W. 2000. Differential impact of carbon assimilation on the expression of quantitative and qualitative resistance in alfalfa (Medicago sativa). Physiol. Mol. Plant Pathol. 57:87-93.

45. Pompe-Novak, M., Gruden, K., Baebler, S., Krecic-Stres, H., Novac, M., Jongsma, M., and Ravnikar, M. 2006. Potato virus Y induces changes in hte gene expression of potato (Solanum tuberosum L.). Physiol. Mol. Plant Pathol. 67:237-247.

46. Punja, Z. K. 2001. Genetic engineering of plants to enhance resistance to fungal pathogens-e-review of progress and future prospects. Can. J. Plant Pathol. 23:216-235.

47. R Development Core Team 2005. R: A Language and Environment for Statistical Computing. R Foundation for Statistical Computing, Vienna, Austria. ISBN 3-900051-07-0, http://www.R-project.org.

48. Read, P. J., Hide, G. A., Firmager, J. P., and Hall, S. M. 1989. Growth and yield of potatoes as affected by severity of stem canker (Rhizoctonia solani). Potato Res. 32:9-15.

49. Richards, B. I. 1921. Pathogenicity of Cortiuim vagum on the potato affected by soil temperature. J. Agric. Res. 21:459-482.

50. Roberts, M. R., and Paul, N. D. 2006. Review - Seduced by the dark side: Interacting molecular and ecological perspectives on the influence of light on plant defence against pests and pathogens. New Phytol. 170:677-699.

51. Ros, B., Thummler, F., and Wenzel, G. 2004. Analysis of differentially expressed genes in a susceptible and moderately resistant potato cultivar upon Phytophthora infestans infection. Mol. Plant Pathol. 5:191201.

52. Sambrook, J., Fritsch, E. F., and Maniatis, T. 1989. Molecular Cloning: A Laboratory Manual. 2nd ed. Cold Spring Harbor Laboratory Press, NY.

53. Sanford, G. B. 1938. Studies on Rhizoctonia solani Kühn. IV. Effect of soil and moisture on virulence. Can. J. Res. 16:203-213.

54. Scholte, K. 1989. Effects of soil-borne Rhizoctonia solani Kühn on yield and quality of ten potato cultivars. Potato Res. 32:367-376.

55. Secor, G. A., and Gudmestad, N. C. 1999. Managing fungal diseases of potato. Can. J. Plant Pathol. 21:212-221.

56. Simons, S. A., and Gilligan, C. A. 1997. Factors affecting the temporal progress of stem canker (Rhizoctonia solani) on potatoes (Solanum tuberosum). Plant Pathol. 46:642-650.

57. Smyth, G. K. 2004. Linear models and empirical Bayes methods for assessing differential expression in microarray experiments. Statistical Applications in Genetics and Molecular Biology, vol. 3: Article 3. Published online by the Berkeley Electronic Press. http://www. bepress.com/sagmb/vol3/iss1/art3.

58. Sneh, B., Burbee, L., and Ogoshi, A. 1991. Identification of Rhizoctonia Species. The American Phytopathological Society, St. Paul, MN.

59. Sneh, B., Jabaji-Hare, S., Neate, S., and Dijst, G., eds. 1996. Rhizoctonia Species: Taxonomy, Molecular Biology, Ecology, Pathology and Disease Control. Kluwer Academic Publishers, Dordrecht, The Netherlands.
60. Stockwell, V., and Hanchey, P. 1987. Lignification of lesion borders in Rhizoctonia-infected bean hypocotyls. Phytopathology 77:589-593.

61. Takemoto, D., Furuse, K., Doke, N., and Kawakita, K. 1997. Identification of chitinase and osmotin-like protein as actin-binding proteins in suspension-cultured potato cells. Plant Cell Physiol. 48:441-448.

62. Tian, Z. D., Liu, J., Wang, B. L., and Xie, C. H. 2006. Screening and expression analysis of Phytophthora infestans induced genes in potato leaves with horizontal resistance. Plant Cell Rep. 25:1094-1103.

63. Van Emden, J. H. 1965. Rhizoctonia solani: Results of recent experiments. Eur. Potato J. 8:188-189.

64. Van Loon, L. C., and Van Strien, E. A. 1999. The families of pathogenesis-related-proteins, their activities, and comparative analysis of PR-1 type proteins. Physiol. Mol. Plant Pathol. 55:85-97.

65. Wasfy, E. H., Sheir, H. M., El-Meteny, A. Y., and Darweesh, M. M. 1984. Changes in peroxidase isoenzyme pattern of bean hypocotyl due to infection with Rhizoctonia solani. Trans. Br. Mycol. Soc. 82:154-156.

66. Weinhold, A. R., Bowman, T., and Hall, D. H. 1982. Rhizoctonia disease of potato-effect on yield and control by seed tuber treatment. Plant Dis. 66:815-818

67. Wen, K., Seguin, P., St.-Arnaud, M., and Jabaji-Hare, S. 2005. Real-time quantitative RT-PCR of defense associated gene transcripts of Rhizoctonia solani-infected bean seedlings in response to inoculation with nonpathogenic binucleate Rhizoctonia isolate. Phytopathology 95:345-353.

68. Venu, R. C., Jia, Y., Gowda, M., Jia, M. H., Jantasuriyarat, C., Stahlberg, E., Li, H., Rhineheart, A., Boddhireddy, P., Singh, P., Rutger, N., Kudrna, D., Wing, R., Nelson, J. C., and Wang, G. L. 2007. RL-SAGE and microarray analysis of the rice transcriptome after Rhizoctonia solani infection. Mol. Genet. Genomics 278:421-431.

69. Vierheilig, H., Alt, M., Neuhaus, J.-M., Boller, T., and Wiemken, A. 1993. Colonization of transgenic Nicotiana sylvestris, expressing different forms of Nicotiana tabacum chitinase, by the root pathogen Rhizoctonia solani and by the mycorrhizal symbiont Glomus mosseae. Mol. PlantMicrobe Interact. 6:261-264.

70. Wilson, P. S., Ahvenniemi, P. M., Lehtonen, M. J., Kukkonen, M., Rita, H., and Valkonen, J. P. T. Biological and chemical control and their combined use to control different stages of Rhizoctonia disease complex on potato through the growing season. Ann. Appl. Biol. (In press.)

71. Wolski, E. A., Maldonado, S., Daleo, G. R., and Andreu, A. B. 2006. A novel $\alpha-1,3$-glucan elicits plant defence response in potato and induces protection against Rhizoctonia solani AG-3 and Fusarium solani f. sp. eumartii. Physiol. Mol. Plant Pathol. 69:93-103.

72. Wolski, E., Maldonado, S., Daleo, G., and Andreu, A. 2007. Cell wall $\alpha-$ 1,3-glucans from a biocontrol isolate of Rhizoctonia: immunocytolocalization and relationship with alpha-glucanase activity from potato sprouts. Mycol. Res. 111:976-984.

73. Xue, L., Charest, P. M., and Jabaji-Hare, S. H. 1998. Systemic induction of peroxidases, $1,3-\beta$-glucanases, chitinases, and resistance in bean plants by binucleate Rhizoctonia species. Phytopathology 88:359-365.

74. Yang, B., Srivastava, S., Deyholos, M. K., and Kav, N. N. V. 2007. Transcriptional profiling of canola (Brassica napus L.) responses to the fungal pathogen Sclerotinia sclerotiorum. Plant Sci. 173:156-171.

75. Yao, M., Tweddell, R., and Désilets, H. 2002. Effect of two vesiculararbuscular mycorrhizal fungi on the growth of micropropagated potato plantlets and on the extent of disease caused by Rhizoctonia solani. Mycorrhitza 12:235-242. 